\title{
Det er ikke alltid \\ sammenheng mellom \\ gode karakterer og gode holdninger
}

Pedagogiske metoder bør vurderes for å gjøre etikkfaget relevant og utviklende.

\section{Terje Årsvoll Olsen}

Medlem av Rådet for sykepleieetikk og førstelektor

Høgskulen på Vestlandet

Sykepleien 2016104 (9) (48 49)

DOI: 10.4220/Sykepleiens.2016.58787

Etikkens plass i sykepleierutdanningen kan synes selvsagt, men likevel kan det virke som om studentene ikke forstår betydningen av etikk som fag. Det kan skyldes læreres formidlingsevne, men også andre forhold påvirker. Utsagn som «I utgangspunktet er de jo både moralske og etisk bevisst når de har valgt å bli sykepleiere», er ikke så uvanlig å høre i utdanningen.

\section{Kraftig debatt}

Sykepleierstudent Cathrine Krøger ved HiOA satte i sving en kraftig debatt om innholdet $\mathrm{i}$ sykepleierutdanningen. Hun er også inne på liknende tanker når hun hevder at etikk er blant de fag det blir undervist for mye $i$. «Den ensidige prioriteringen av teori, fagterminologi, kommunikasjon og etikk, går på bekostning av realfag som anatomi og fysiologi.», skriver hun. (1) 
Jeg trekker det antakelig langt ved å påstå at Krøger har sagt at etikk ikke er viktig. Jeg tenker at hun mener at andre fag er viktigere. Det er flere tanker å gjøre seg rundt det. Hvilken tilnærming skal vi ha til etikkfaget, og når skal faget introduseres? Dette er ikke etiske dilemma, men det er pedagogiske overveielser for å gjøre faget relevant og utviklende.

\section{Må fenge studentene}

Hvordan sikrer vi at alle studentene kommer til timene når etikk står på planen, når enkelte egentlig synes vi heller burde har mer undervisning $i$ anatomi og fysiologi og medikamentregning og de derfor prioriterer å være hjemme eller på lesesalen? Hjelper det å gjøre faget obligatorisk? Da kommer de, men er de til stede?

På store utdanningsinstitusjoner kan det være 80-200 studenter på forelesningen. Man skal være litt av en entertainer for å fange alle disse med etisk filosofi og sykepleiens etiske grunnlag. Etikk, etikette og estetikk bør selvsagt gjennomsyre all undervisning innen sykepleiens ulike aspekt.

Det er en utfordring i dag at ressursene til undervisning blir mindre og mindre. Samtidig utfordres vi til å finne og ta i bruk nye læringsformer. Professor i sosiologi ved NTNU, Arne Krokan vil forby forelesninger (2). Han vil digitalisere det hele. Teambased-learning er en ny trend der forelesningen foregår på nett og debatten i klasserommet. Men hvordan kan vi skape debatt når studentene mener de allerede har høy etisk standard og de sitter foran PCen eller lesebrettet? 
Sykepleierutdanningen er i dag plassert i laveste kategori hva finansiering angår. Dette får konsekvenser for en-til-en-oppfølging av studentene. I store grupper har etikken dessverre lett for å bli et spørsmål om «OsS» og «de andre». «Vi er flinke og etiske i vårt sinnelag. Det er ingen i vår klasse som ikke handler rett. Jeg vil aldri jobbe på et slikt sted som ikke setter pasienten først.» Likevel er det slik at det er helsepersonellets oppførsel pasientene klager mest på.

\section{Daglige krenkelser}

Ifølge Norsk pasientforening skjer krenkelser daglig i norsk helsevesen. Jeg vet at det er mange årsaker som kan forklare dette, men det blir likevel bortforklaringer. Enkelte av mine studenter har etter praksisperioder rapportert at de har reagert på dårlig oppførsel og dårlige holdninger hos grupper av ansatte i feltet, men de har ikke våget å utfordre det underveis av frykt for å få problemer og kanskje ikke bestå praksis. Det tydeliggjør for meg at lærere må ha en sentral plass i praksisfeltet og ha trygghet og tyngde nok til å ta de etiske debattene. I dag er vi bare på visitt og har ikke anledning til å være i pasientsituasjoner på grunn av taushetspliktens bestemmelser.

Etikkundervisningen må flyttes ut av klasserommene, inn i grupperommene og ut i praksisfeltet, og ledere av sykepleietjenesten bør være engasjert i studentenes etiske undring.

\section{Karakterskala og autorisasjon}

Sykepleierutdanningen er en bachelor på 180 studiepoeng, der 50 prosent av studiene foregår i praksis. Studentene har en rekke eksamener og passeringsoppgaver både i teoribolkene og i praksis. Høyere utdanning har et karaktersystem fra A-F, der både A, B, C, D og E gir rett til en bachelor og dermed autorisasjon som sykepleier. 
Hva betyr karakterene: A er fremragende prestasjon som klart utmerker seg. B er meget god og C er god. Mens D sier: Kandidaten viser en viss grad av vurderingsevne og selvstendighet, og E: liten vurderingsevne og selvstendighet. F er grei: «ikke bestått», og studenten kommer ikke videre i utdanningen. Men med D og E kan du få autorisasjon.

Kun to av tolv utdanningsinstitusjoner som deltok i deleksamen i anatomi/fysiologi i 2015 har et karaktersnitt på C, mens hele seks har E. Betyr det at de blir dårlige sykepleiere? Med dagens nivå på inntak til utdanningen burde kanskje D og E ikke eksistere?

\section{Skikkethetsvurdering og dannelse}

Burde slike karakterer være grunnlag for en skikkethetsvurdering? I forskrift om skikkethetsvurdering står det at en student er uskikket i utdanningene dersom ett eller flere av kriteriene er oppfylt. Mitt inntrykk er at praksis i liten grad kjenner til skikkethetsforskriften (3). En E i anatomi vil neppe bli oppfattet som grunnlag for en skikkethetsbekymring, men vil en E i sykepleie eller etikk være det?

Ingen av punktene i skikkethetsforskriften gir slike føringer etter eksamensresultater, men etter praksissituasjoner kan saken være annerledes. Men bare hvis praksis kjenner sitt ansvar og skolen og praksis er modige nok? Danning krever at en blir sett, og at det gis rom for egenrefleksjon. Studentene må få tilbakemeldinger som kan være med på å videreutvikle både faglig og personlig vekst. Dette skjer ikke i korte møter, men over tid. 
På desentralisert sykepleierutdanning ved Høgskolen i Bergen følger vi studentene gjennom fire år, og vi legger stor vekt på at utdanningen handler like mye om danning som utdanning. Gjennom årlige individuelle samtaler, i tillegg til alle evaluerings- og veiledningssamtalene, bruker vi mye tid på hvem studenten vil bli som sykepleier på det personlige plan. Vi ser at det ikke alltid er sammenheng mellom gode karakterer og gode holdninger og evner til å se og møte pasientene, pårørende og kollegaer.

\section{Referanser:}

1. Krøger C. Flere mastere? Skrekk og gru.

http://www.aftenposten.no/meninger/debatt/Fleremastere-Skrekk-og-gru--Cathrine-Kroger-10839b.html (14.9.2016)

2. Lindholm A. Foreslår å forby forelesninger. http://khrono.no/2016/06/digitalisering-i-hoyereutdanning) (18.07.2016)

3. LOVDATA. Forskrift om skikkethetsvurdering i høyere

utdanninghttps://lovdata.no/dokument/SF/forskrift/200606-30-859 (18.07.2016)

\section{«Man skal være litt av en entertainer for å fange alle disse med etisk filosofi og sykepleiens etiske grunnlag.»}

